DOI https://doi.org/10.32405/2522-9958-8(37)-35-45

UDC: 37.01:373.01:005

\author{
Nataliia Klokar, \\ Doctor of Educational Sciences, \\ Professor, Honored Worker of Education of Ukraine, \\ the first vice-rector, prorector of scientific and pedagogical, \\ educational work of the \\ SIHE «University of Educational Management». \\ Kyiv, Ukraine. \\ ORCID iD: https://orcid.org/0000-0003-2487-7483 \\ ni-taurus@ukr.net
}

\title{
DEVELOPMENT OF UKRAINIAN SCHOOL PRINCIPAL'S PROFESSIONAL STANDARDS: KEY APPROACHES
}

\begin{abstract}
The article deals with the problem of development of Ukrainian School Principal's Professional Standards. The Concept for the Implementation of the State Policy in the Reform of General Secondary Education «New Ukrainian School» is an important part of modernization of Ukrainian system of education. The success of school reform depends on professionalism of School Principals. It's very actual to develop the Professional Standards for Ukrainian School Principals \& the system of School Principals' preparation. The process of preparing Professional Standards has to foresee such focuses as Strategy of School development, Management culture, Management of educational process, Staff development, Collaboration \& Partnership with their school management practice \& profiles. There's a necessity to moderate levels of School Principals' preparation: Bachelor degree, Master degree, Life Long Learning (In-Service Education, Self-Education, Self-growth).
\end{abstract}

Key words: New Ukrainian School; School Principals; Professional Standards; key approaches, levels of preparation.

\section{INTRODUCTION / ВCTУП}

Formulation of the problem. Democratic changes in Ukraine, decentralization of power, increasing role of local communities causes the modernization of school system education on all levels [1]. The Concept for the Implementation of the State Policy in the Reform of General Secondary Education «New Ukrainian School» [2], [3] is a background for building a new system of school education with its new structure \& content in accordance with European educational standards. The realization of this reform depends on 
School Principals' readiness for changes, the compliance of professional competences with state standards of Ukrainian School Principal which must be developed \& implement in school practice.

Literature overview / Аналіз останніх досліджень і публікацій. The theoretical \& methodological foundations for professional preparation of educational managers, their professional development \& managerial competences, the process of their life long education, key approaches of their professional activity is revealed in the numerous works of Ukrainian (L. Vashchenko, L. Danylenko, G. Dmytrenko, G. Yelnikova, L. Kalinina, S. Kalashnikova, N. Klokar, V. Kremen', V. Lugoviy, V. Maiboroda, V. Maslov, V. Oliynyk, S. Pazynich, N. Protasova, G. Tymoshko, T. Sorochan etc.) \& foreing researchers (S. Baker, \& E. Gerler (2008) [4], N. Bennett, J. Harvey, C. Wise, P. Woods (2003) [5], T. Bush (2011) [6], P. Drucker (2001) [7], K. Leithwood, C. Day, P. Sammons, A. Harris, D. Hopkins (2006) [8], B. Mulford (2008) [9], J. Sebastia, (2018) [10] etc.). At that time, the specific character of Ukrainian school principals' standards were not researched. There's a necessity to develop key approaches of School Principal's standards \& the ways to improve the system of their preparation in Ukraine on the levels of Bachelor \& Master degrees, Life Long Learning.

\section{AIM AND TASKS / META TA ЗАВДАННЯ}

Objective statement of the paper / мета статті. The overall purpose of this paper is to develop key approaches of the Ukrainian School Principal's Professional Standards \& the ways to improve the system of their preparation on the levels of Bachelor \& Master degrees, Life Long Learning.

Objectives of the study / завдання дослідження: pay attention to the necessity to develop \& implement the Ukrainian School Principals' Professional Standards; describe key approaches of such professional standards: focus, school management practice \& profiles; describe the main steps of School Principals preparation \& professional development to achieve the given standards; anticipate prospects for further research of the problem.

\section{THE THEORETICAL BACKGROUNDS / TEOPETИЧHI ОСНОВИ ДОСЛІДЖЕННЯ}

At the stage of theoretical comprehension of the studied problem, general methods and techniques of cognition were used: analysis of legal documents concerning the modernization of the Ukrainian system of education and scientific and pedagogical literature on the issues of requirements for participation in the competition for the position of the school principal, introduction of educational standards, preparation of future educational managers, comparing the positions of 
scientists with the content of the concept of "professional standards", systematization and generalization of theoretical data to determine the key approaches for development of School Principal's standards.

\section{RESEARCH METHODS / МЕTОДИ ДОСЛІДЖЕННЯ}

Methods. 147 principals were purposively selected for the purposes of the study. Semi-structured interviews were conducted with the principals of the 23 schools and a questionnaire was completed by 14 professors in the National Academy of Educational Sciences of Ukraine. The methods used in collecting data were through a semi-structured interview and a questionnaire. The conceptual framework of this paper was based on the necessity to analyze the key approaches \& foresee basic focuses for development of Professional Standards for School Principal.

\section{RESEARCH RESULTS / РЕЗУЛЬТАТИ ДОСЛІДЖЕННЯ}

The statement of basic materials. The Ukrainian School Principal's Professional Standards provide a framework for what a School Principal should know, understand and do to succeed as a person who provides results \& develops an organization.

School Principal:

- is a citizen of Ukraine;

- has higher pedagogical education;

- has a master degree in management («Public management and administration» or «Management of Educational Establishment»);

- has not less than 3 years of school practice;

- is fluent in the state language.

The professional activity of a School Principal should be concentrated on several key focuses with relevant school management practice \& profiles [11].

\section{Focus: Strategy of School development.}

School management practice: Work with others to produce \& implement clear, evidence-based improvement plans \& policies for the development of school \& its facilities, to lead \& to manage innovation \& change.

Profiles:

- Thinks strategically, critically;

- Accepts new, generates innovations;

- With the board, develops and then implements a school vision with shared goals and values focused on enhanced engagement and achievement (academically, socially and culturally) for all students; 
- Operates effective systems within board policy and in accordance with legislative requirements;

- Knows the methodology of forming a strategic framework (program) for the development of school;

- Uses school / external evidence to inform planning for future action, monitor progress and manage change; objectives;

- Aligns resource allocation with the school's annual and strategic

- Able to develop and implement educational projects and programs, organize educational research;

- Shows initiative and determination.

Focus: Management culture.

School management practice: Provide professional leadership that focuses the school culture on enhancing learning and teaching.

Profiles:

- Has the competencies of education leader of the 21st century;

- Exhibits leadership that results in the effective day-to-day operation of the school;

- Works in a team, motivating staff to move towards a common goal;

- Is able to adapt and act effectively in a new situation;

- Identifies and solves problems;

- Makes informed decisions;

- Has an active civic position, operates in a socially responsible manner;

- Works autonomously;

- Has developed communication skills;

- Manages conflict and other challenging situations effectively and actively works to achieve solutions;

- Knows and uses time management technology;

- Uses modern ICT, digital technologies, modern teaching methods;

- Demonstrates leadership in professional practice, through applying critical inquiry and problem solving;

- Effectively manages finance, property, health and safety systems;

- Adheres to the legislation, promotes the provision of social guarantees to employees of the institution;

- Is critically suited to assessing yourself and his/her managerial actions/activity;

- Knows the ways to prevent corruption in an institution of education. 


\section{Focus: Management of educational process.}

School management practice: Create a learning environment in which there is an expectation that all students will experience success in learning.

Profiles:

- Knows the conceptual foundations of childhood centeredness, partnership pedagogy;

- Demonstrates leadership through engaging with staff and sharing knowledge about effective teaching and learning in the context of the Ukrainian curriculum documents;

- Knows the state standard and programs of Ukrainian school;

- Knows the basic requirements for determining learning outcomes and assessing student achievement;

- Ensures the use of best practices for assessment, and analyses and acts upon evidence on student learning to maximize learning for all students;

- Maintains a safe, learning-focused environment;

- Focuses in particular on success in learning for students with special education needs, and students at risk of not succeeding at school;

- Promotes and supports the gaining of worthwhile qualifications and successful transitions to get high-quality education or employment for all students.

\section{Focus: Staff development.}

School management practice: Support all staff to achieve high standards of their professional activity in order to ensure the quality of students' education.

Profiles:

- Motivation for career development;

- Is able to form and develop the staff of the school;

- Promotes, participates in and supports ongoing professional learning linked to student progress;

- Knows team building, is able to create a team \& delegates of authority;

- Creates challenging roles, responsibilities \& opportunities for professional development of school teachers;

- Seeks opportunities for professional growth through engaging in state, national, regional \& international educational programs;

- Uses a supervisory technique for professional development of school staff.

Focus: Collaboration \& partnership.

School management practice: Strengthen communication and relationships to enhance student learning.

Profiles:

- Implementation of public-private partnership in education; 
- Is able to form a democratic model of school management;

- Is able to establish effective interaction of educational institutions, authorities and communities of different levels;

- Works with the board to facilitate strategic decision-making, staff members work collaboratively to improve teaching and learning;

- Is able to attract stakeholders to create comfortable conditions for obtaining quality education;

- Maintains positive relationships with the school \& local community;

- Ensures regular interaction with parents and the school community on student's progress;

- Actively fosters positive relationships with other schools and participates in appropriate school networks.

Taking into account the described focuses for Professional Standards of a School Principal, there's a necessity to analyze key steps to achieve the level of these standards (Figure).

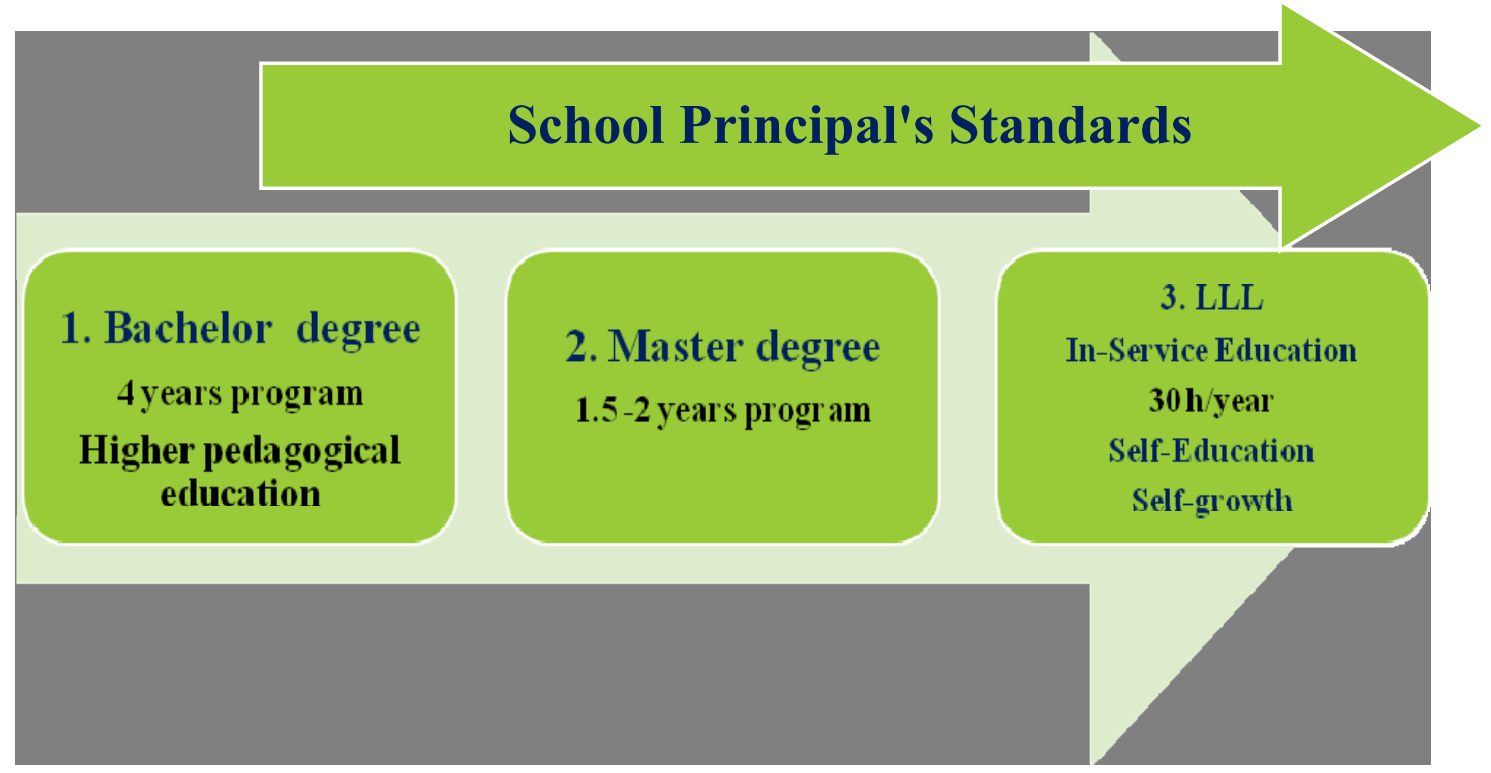

Figure. Key steps to achieve the level of School Principal's Standards

\section{Bachelor degree}

Preparation of future school subjects teachers. During four years there should be a program for monitoring and identifying future educational leaders. Starting from the $3^{\text {rd }}$ year it's quite possible to suggest those who have shown propensity for management work and leadership enthusiasm a special motivational course of school leadership (90-120 hours, including practice with the best School Principals) in order to support students' motivation to become a School Principal. 


\section{Master degree}

1.5-2 years program of leadership \& school management. The content of the program should be oriented on formation the competences provided by the standards of the School Principal.

3. LLL - lifelong learning: development the competences provided by the standards of a School Principal.

In-Service Education. $150 \mathrm{~h}$ In-Service module program for School Principals ( 5 modules $\times 30$ h/year).There's a possibility for a School Principal to choose any kind of module (full-time \& distant courses) at any educational institution which has a license for In-Service Education. Participation in different kinds of seminars, conferences, trainings, workshops etc. \& getting certificates.

\section{Self-Education \& Self-growth.}

Take advantage of free educational resources, use tools and platforms that facilitate self-directed learning, make learning a habit, organize a group study with co-workers or friends, apply what you learn, question everything, share what you've learned etc [12].

\section{CONCLUSIONS AND PROSPECTS FOR FURTHER RESEARCH / ВИСНОВКИ ТА ПЕРСПЕКТИВИ ПОДАЛЬШИХ ДОСЛІДЖЕНЬ}

Thus, such theoretical and methodological background to the analysis of key approaches of School Principals' standards is explained by the necessity to attract attention of researchers \& practitioners to the problem of development \& implementation of the Ukrainian School Principals' Professional standards \& the ways to improve the system of their preparation on the levels of Bachelor \& Master degrees, Life Long Learning.

The results of our experimental research explane what a School Principal should know, understand and do to succeed as a person who provides results \& develops an organization. Special attention should be directed to focus, school management practice \& profiles of School Principals' activity, modernization of content \& forms of future School Principals' preparation, development the system of LLL.

Prospects for further research / Перспективи подальших досліджень. Further studies consider it expedient to focus on the development of the problem of methodology of creating state professional standards in education, the professional competences of the New Ukrainian School Principals, the ways of improvement of self-education \& self-growth in the process of professional development, the influence of early professional orientation on the identification of leadership positions of the future School Principal, improving the efficiency of professional development of School Principals in the system of Post Graduate education. 
Вісник післядипломної освіти. Випуск 8(37) «Серія «Управління та адміністрування» https://doi.org/10.32405/2522-9958

\section{7. СПИСОК ВИКОРИСТАНИХ ДЖЕРЕЛ / REFERENCES (TRANSLATED AND TRANSLITERATED)}

[1] Law of Ukraine «On Education» of 09.05.2017 № 2145-VIII // Bulletin of the Verkhovna Rada of Ukraine, (2017). \# 38/39. Art. 380 [in Ukrainian].

[2] Approval of the Concept for the Implementation of the State Policy in the Reform of General Secondary Education «New Ukrainian School» for the period until 2029. Order of the Cabinet of Ministers of Ukraine No. 988-p dated December 14, 2016.

[3] Concept, (2017). Official Bulletin of Ukraine, 1. P. 84 / Official site of the Verkhovna Rada of Ukraine [Electronic resource]. Access mode: http://zakon2.rada.gov.ua/laws/show/988-2016-\%D1\%80.

[4] S. B. Baker \& E. R. Gerler, (2008). School counseling for the twenty-first century (5th ed.). Upper Saddle River, NJ: Pearson [Electronic resource].

Access mode: https://www.pearson.com/us/higher-education/program/BakerSchool-Counseling-for-the-21st-Century-5th-Edition/PGM94720.html

[5] N. Bennett, J. Harvey, C. Wise, P. Woods (2003). Distributed Leadership: A Desk Study. Nottingham: NCSL (National College for School Leadership). [Electronic resource]. http://oro.open.ac.uk/8534/

[6] T. Bush, (2011). Theories of Educational Leadership and Management, 4th ed. London: Sage [Electronic resource].

https://www.amazon.co.uk/Theories-Educational-Leadership-

Management-Tony/dp/1848601913

[7] F. Peter, Drucker, (2001). Management Challenges for the 21st Century [Electronic resource]. https://www.amazon.com/ManagementChallenges-Century-Peter-Drucker/dp/0887309992

[8] K. Leithwood, C. Day, P. Sammons, A. Harris, D. Hopkins, (2006). Seven Strong Claims about Successful School Leadership. Nottingham: NCSL (National College for School Leadership) [Electronic resource]. https://dera.ioe.ac.uk/6967/1/download\%3Fid=17387\&filename=sevenclaims-about-successful-school-leadership.pdf

[9] B. Mulford, (2008). The Leadership Challenge: Improving learning in schools [Electronic resource]. https://research.acer.edu.au/aer/2/

[10] J. Sebastian, (2018). Principal Leadership and School Performance: An Examination of Instructional Leadership and Organizational Management [Electronic resource].

https://www.tandfonline.com/doi/abs/10.1080/157007

[11] Australian Professional Standard for Principals and the Leadership Profiles, (2014) [Electronic resource]. https://www.aitsl.edu.au/docs/defaultsource/default-document-library/australian-professional-standard-forprincipals-and-the-leadership-profiles 
[12] P. Jun, Never Stop Learning: How Self-Education Creates a Bullet-Proof Career [Electronic resource]. https://99u.adobe.com/articles/29995/never-stop-learning-how-selfeducation-creates-a-bullet-proof-career

\title{
СТВОРЕННЯ ПРОФЕСІЙНИХ СТАНДАРТІВ ДИРЕКТОРА УКРАЇНСЬКОЇ ШКОЛИ: КЛЮЧОВІ ЗАСАДИ
}

\author{
Клокар Наталія Іванівна, \\ доктор педагогічних наук, професор, \\ заслужений працівник освіти України, \\ перший проректор - проректор 3 \\ науково-педагогічної та навчальної роботи \\ ДЗВ0 «Університет менеджменту освіти». \\ Київ, Україна. \\ ORCID iD: https://orcid.org/0000-0003-2487-7483 \\ ni-taurus@ukr.net
}

Анотація. Статтю присвячено проблемі розробки професійних стандартів директора української школи. Концепція реалізації державної політики в сфері реформування загальної середньої освіти «Нова українська школа» $\epsilon$ важливою складовою модернізації української системи освіти. Успіх реформи залежить від професіоналізму шкільних директорів. Актуальним $\epsilon$ розробка професійних стандартів для директорів українських шкіл i удосконалення системи їхньої підготовки. Професійні стандарти повинні передбачати такі напрями, як стратегія розвитку школи, культура управління, управління навчальним процесом, розвиток персоналу, співпраця і партнерство 3 відповідною шкільною практикою і профілями управління закладом. У зв'язку з цим уваги потребує питання модернізації змісту і форм виявлення та підготовки майбутніх директорів шкіл на рівнях бакалавра i магістра. Окрема увага має зосереджуватися на проблемі пожиттєвого навчання керівників шкіл (підвищення кваліфікації, самоосвіта, саморозвиток), що сприяє досягнення ними рівня державних професійних стандартів.

Кючові слова: Нова українська школа; директор школи; професійні стандарти; ключові засади; рівні підготовки. 


\title{
СОЗДАНИЕ ПРОФЕССИОНАЛЬНЫХ СТАНДАРТОВ ДИРЕКТОРА УКРАИНСКОЙ ШКОЛЫ: КЛЮЧЕВЫЕ ПОДХОДЫ
}

\author{
Клокарь Наталия Ивановна, \\ доктор педагогических наук, профессор, \\ заслуженный работник образования Украины, \\ первый проректор - проректор \\ по научно-педагогической и учебной работе \\ ГЗВО «Университет менеджмента образования». \\ Киев, Украина. \\ ORCID iD: https://orcid.org/0000-0003-2487-7483 \\ ni-taurus@ukr.net
}

Аннотация. Статья посвящена проблеме разработки профессиональных стандартов директора украинской школы. Концепция реализации государственной политики в сфере реформирования общего среднего образования «Новая украинская школа» является важной составляющей модернизации украинской системы образования. Успех школьной реформы зависит от профессионализма школьных директоров. Актуальным является вопрос разработки профессиональных стандартов для директоров украинских школ и модернизации системы их подготовки. Профессиональные стандарты руководителя общеобразовательного учебного заведения должны предусматривать такие направления, как стратегия развития школы, управленческая культура, управления учебным процессом, развитие персонала, сотрудничество и партнерство с соответствующей школьной практикой и профилями управления учреждением. В связи с этим внимание должно быть уделено вопросу модернизации форм и содержания поиска и подготовки будущих директоров школ на уровнях бакалавра и магистра. Отдельное внимание - вопросу пожизненного обучения руководителей школ (курсы повышения квалификации, самообразование, саморазвитие), что способствует достижению ими уровня государственных профессиональных стандартов.

Ключевые слова: Новая украинская школа; директор школы; профессиональные стандарты; ключевые подходы; уровни подготовки.

\section{REFERENCES (TRANSLATED AND TRANSLITERATED)}

[1] Law of Ukraine «On Education» of 09.05.2017 № 2145-VIII // Bulletin of the Verkhovna Rada of Ukraine, (2017). № 38/39. Art. 380 [in Ukrainian].

[2] Approval of the Concept for the Implementation of the State Policy in the Reform of General Secondary Education «New Ukrainian School» for the 
period until 2029. Order of the Cabinet of Ministers of Ukraine No. 988-p dated December 14, 2016.

[3] Concept, (2017). Official Bulletin of Ukraine, 1. P. 84 / Official site of the Verkhovna Rada of Ukraine [Electronic resource]. Access mode: http://zakon2.rada.gov.ua/laws/show/988-2016-\%D1\%80.

[4] S. B. Baker \& E. R. Gerler, (2008). School counseling for the twenty-first century (5th ed.). Upper Saddle River, NJ: Pearson [Electronic resource]. https://www.pearson.com/us/higher-education/program/Baker-SchoolCounseling-for-the-21st-Century-5th-Edition/PGM94720.html

[5] N. Bennett, J. Harvey, C. Wise, P. Woods (2003). Distributed Leadership: A Desk Study. Nottingham: NCSL (National College for School Leadership). [Electronic resource]. http://oro.open.ac.uk/8534/

[6] T. Bush, (2011). Theories of Educational Leadership and Management, 4th ed. London: Sage. [Electronic resource].

https://www.amazon.co.uk/Theories-Educational-LeadershipManagement-Tony/dp/1848601913

[7] F. Peter, Drucker, (2001). Management Challenges for the 21st Century. [Electronic resource]. https://www.amazon.com/ManagementChallenges-Century-Peter-Drucker/dp/0887309992

[8] K. Leithwood, C. Day, P. Sammons, A. Harris, D. Hopkins, (2006). Seven Strong Claims about Successful School Leadership. Nottingham: NCSL (National College for School Leadership). [Electronic resource]. https://dera.ioe.ac.uk/6967/1/download\%3Fid=17387\&filename=sevenclaims-about-successful-school-leadership.pdf

[9] B. Mulford, (2008). The Leadership Challenge: Improving learning in schools. [Electronic resource]. https://research.acer.edu.au/aer/2/

[10] J. Sebastian, (2018). Principal Leadership and School Performance: An Examination of Instructional Leadership and Organizational Management. [Electronic resource].

https://www.tandfonline.com/doi/abs/10.1080/157007

[11] Australian Professional Standard for Principals and the Leadership Profiles, (2014). [Electronic resource].

https://www.aitsl.edu.au/docs/default-source/default-documentlibrary/australian-professional-standard-for-principals-and-theleadership-profiles

[12] P. Jun, Never Stop Learning: How Self-Education Creates a Bullet-Proof Career. [Electronic resource]. https://99u.adobe.com/articles/29995/never-stop-learning-how-selfeducation-creates-a-bullet-proof-career 